\title{
MUSIC AND THE 'ANY-SPACE-WHATEVER': Translating existential chaos into artistic composition
}

\author{
Transforming Cultures eJournal, \\ Vol. 4 No 1, April 2009 \\ http://epress.lib.uts.edu.au/journals/TfC
}

\section{John Scannell ${ }^{1}$}

\begin{abstract}
This paper looks at the importance of rhythmic creativity for the AfricanAmerican musician as a means of counteracting the inherent "non-space" of diasporic existence. Drawing upon the work of Deleuze and Guattari, as well as from the fields of cultural studies and diaspora theory, this paper examines the immanent existential and territorial concerns of the "minor" subject, as might be witnessed in the music of James Brown. Rather than attribute Brown's AfricanAmerican identity as the defining characteristic of his musical style, as many previous academic accounts have done, I will instead look at his work as the product of a lack of an identity, and how this idea might be understood in relation to Augé's "non-places", the idiosyncratic interpretation of Augé by Deleuze in his Cinema books, and the possible correspondence of this concept of the "non-place"/"any-space-whatever" with the rhizomorphic, post-national. The Black Atlantic subject described by Paul Gilroy. Rather than simply attribute Brown's music as a reiteration of African diasporic musical legacy, the paper instead attempts to define Brown's funk as the work of a becoming-subject, where the creativity of the minority in these "any-space-whatevers" is due to being thrown into the creative chaos of an intolerable position.
\end{abstract}

\section{Introduction: non-place}

Whilst music's 'production of place' has been the main tenet of this symposium, I am somewhat wary of attributing it any such power. Most claims about music's evocation of place are, to my mind, simply nominal, retroactively attributed psychogeographies relative only to the minds of their beholders. Not that such musically inspired evocation is unimportant, it is just that it is too equivocal, and thus too speculative, to have any real theoretical utility.

\footnotetext{
${ }^{1}$ John Scannell is Lecturer in the Department of Media, Music and Cultural Studies at Macquarie University, Sydney, Australia.
} 
Thus, instead of valorising music's 'production of place', I propose that we would learn more by analysing its relation to non-place. For as I argue in this paper, I believe that it is the very anxiety surrounding one's lack of belonging to place which provides the catalyst for artistic expression. Art results from a need to establish a stable consistency within the chaos of the 'non-place' ; an idea that has informed the well-known DeleuzeGuattarian concept of the refrain. I believe that music is simply a territorial refrain created in lieu of 'belonging' to a place, and, if anything, is an artistic response driven by a deeper existential sense of 'not-belonging'. I use 'not-belonging' here, rather than non-identification, because one, can, of course, identify with not-belonging, yet still remain afflicted by the implicit sense of existential disarray that such a state infers. In fact, the more one feels that they don't belong, the more noise they tend to make. Which is why some of the most rhythmically intensive, i.e. territorial, of musical styles, will emerge from some of the most marginal of communities.

Hence I argue for the inextricable link between music and the non-place or 'any-spacewhatever'. The latter term, translated as the 'any-space-whatever', derives from Gilles Deleuze's, Cinema 1: the Movement Image, with reference to Marc Augé's 'non-place'. For Deleuze, the any-space-whatever becomes, '...a space of virtual conjunction, grasped as pure locus of the possible' (Deleuze, 1986:109). Ever the optimist, Deleuze valorises the non-place/any-space-whatever for its unique becoming-potential, a point subsequently taken up by Brian Massumi: 'Cherish derelict spaces. They are holes in habit, what cracks in the existing order appear to be from the molar perspective... The derelict space is a zone of indeterminacy that bodies-in-becoming may make their own' (Massumi 1992: 104).

In the course of this paper, I will place particular emphasis on some rhythmically prominent African-American music styles, including the work of James Brown, hip-hop and electronic dance musics, as a few of the musical styles that have evolved from anyspace-whatevers. For example, hip-hop's emergence from the Bronx, in the late 1960s, is to my mind, a musical phenomenon that would attempt to counteract, rather than empirically reflect, the systematic erosion of community from which it arose. As Tricia Rose details in her book, Black Noise, it was the construction of the Cross-Bronx Expressway, started in the late 1940s, but finally completed in the early 1960s, that would rather rudely striate the former working class community and otherwise assist in 
the erosion of its social fabric. Indeed, there is perhaps no better example of the twentieth century's triumph of the 'non-place' than the Cross-Bronx Expressway project, and correspondingly, no better example of the type of communal decimation it perpetuates. Yet it was the attempt to reclaim a sense of place, that the DJs, most famously, Kool Herc and Afrika Bambaataa, hit the parks with their sound systems to reinforce a territorial presence within this broader existential condition of non-place.

Whilst hip-hop, is, of course, eminently notable for its calls to 'represent' particular localities through a systematic name-dropping of often very specific geographical landmarks, the musical content itself is always dislocated from its immediate temporal/geographical origins. Hip-hop is a style that is constructed, more often than not, out of decades-old samples. These samples of old records, I would argue, are mobilised in order to transcend locality and instead drive a strategic reterritorialising undertaken to project a collectivity that does not exist. By extension, the oft-cited 'elements' of hip-hop culture - graffiti, breaking, DJing and MCing, might also be considered as territorialising strategies undertaken to signify presence in (often derelict) urban any-spaces-whatever.

The Bronx is, of course, only one example of the many such derelict spaces that have accounted for a rhythmically driven attempt to challenge non-place. Other notable examples might include, Detroit (home of Techno), Chicago (home of House), Kingston Jamaica (home of Reggae), even Düsseldorf Germany, where Kraftwerk would hone their futuristic image as a way of transcending Germany's then-recent wartime past. Whilst space precludes a systematic history of these hotbeds of electronic dance music culture, what they have in common is their respective musical styles, all of which create musical territories in lieu of a sense of belonging. The fact that the Hip-Hop and electronica genres are so readily transportable to, and adapted by disparate communities the world over (think for example of the oft-heralded concept of a global 'Hip-hop Nation'), undermines any actual fidelity to a specific 'place'. The global Hip-hop Nation is thus utopian in the most literal sense, a commodity-driven 'no-place' exemplary of post-industrial capitalist supermodernity. In order to count yourself among its members all you have to do is buy the records and look the part. 


\section{Augé's 'Non-Places' and Deleuze's Any-Space-Whatever}

This brings us to the very concept of non-place itself. Augé's Non-Places: Introduction to an Anthropology of Supermodernity details the increasing prevalence of '... spaces which are not of themselves anthropological places' (Augé 1995: 78) but are instead, '...spaces formed in relation to certain ends (transport, transit, commerce, leisure)...' (ibid. 94): Augé will argue that these 'non-places', airport transit lounges, supermarket checkouts, fast food restaurants and even road signs (1995: 96-101) are mediated only through the signifiers of commerce and exist only for commodification. According to Augé, vast numbers of individuals move anonymously through these abstract spaces mediated only for the purposes of fulfilling commercial contracts (ibid. 101-102). The 'non-place' is thus distinguished from the organic, 'anthropological space' for the very reason that '....anthropological places create the organically social' in distinction to these 'non-places' that '...create solitary contractuality' (ibid. 94).

On the surface, Augé's non-place would hardly appear conducive to creative activity, yet for Deleuze, it is quite the opposite. Thus, Deleuze's idiosyncratic interpretation of Augé will transform the concept of the non-place from its innately pessimistic presentation to the more optimistic outlook it receives in Deleuze's Cinema 1: the Movement Image, as the any-space-whatever (espace quelconque). ${ }^{2}$ For the record, there has been some confusion over Deleuze's reading of the concept for a couple of reasons, primarily because the concept of the 'any-space-whatever'. whilst similar to Augé's concept, is not a direct translation of 'non-lieux' (non-place). As noted by Charles Stivale, whilst authors such as Reda Bensmaia assume that Deleuze is drawing '...extensively from Marc Augé in his essay...it is not clear at all that Marc Augé uses the actual term 'espace quelconque“ itself' (Stivale 2005). Secondly, whilst Deleuze does attribute the any-space-whatever to an Augé, it is to a 'Pascal' Augé, rather than to Marc Augé. As Cinema 1 actually came out around the same time as Augé's own publications on nonplaces, including Un ethnologue dans le métro (1986), perhaps Deleuze had been privy to an early version of Augé's work and simply just botched the attribution? One would have to assume so, as most of Deleuze's analysis of 'Pascal' Augé's any-space-whatever

\footnotetext{
${ }^{2}$ There has been some confusion as to the attribution of authorship. For Deleuze will refer to Marc Augé as 'Pascal' Augé. Given that the concept of the 'any-pace-whatever' whilst similar, is not a direct translation of 'non-lieux' which as Charles Stivale notes whilst authors such as Reda Bensmaia will draw '...extensively from Marc Augé in his essay... it is not clear at all that Marc Augé uses the actual term 'espace quelconque' itself' (Stivale 2005).
} 
has many similarities with Marc Augé's non-place.

The Deleuzean any-space-whatever will thus emphasise the lack of belonging in these spaces, where, '... individuals become depersonalized. No one notes or concerns themselves with one another. The place is crowded but everyone is alone. It is for this reason, that Augé's 'any space whatsoever' is a homogenous, de-singularizing space' (Bell 1997). Yet, in distinction to Augé's more dystopian vision of the proliferation of 'non-places'. for Deleuze, this lack of identity might also offer infinite possibility for connection (Deleuze 1986:109). Whilst I will return to this seemingly paradoxical relationship between non-place and creative connection, for present purposes we need only to understand that this productivity is actually the result of the inherent chaos of these any-space-whatevers, a chaos that can only be counteracted through the creation of territory.

Rather than being driven by attempts to reflect geographical space or place, the raison d'etre of the aforementioned dance music styles is the creation of territory. The fact that these musics are, more often than not, the domain of minority youth cultures, is because it is this demographic that tends to (over)compensate for their relative lack of presence. In such cases, music is used to mediate the chaos of a lack of identity, and to produce territory where there is none, a necessary means of mediating both physical and existential any-space-whatevers. The car of the young, male minority drives down the anonymous freeway with a subwoofer in the boot. It is making sense of this relationship between existential habitus and its relationship with musical production that Deleuze's any-space-whatever proves so very useful. For Deleuze's transformation of Augé's concept of the 'non-place' into the any-space-whatever allows it to become a catalyst for productivity, which, '[i]n contrast to Augé...rather than being an homogenizing and de-singularizing force...shows that for Deleuze the 'any space whatsoever' is a condition for the emergence of uniqueness and singularities' (Bell 1997).

The undulating rhythms of James Brown's burgeoning funk style, for example, which did so much to shape the aforementioned contemporary dance music genres, might also be seen as another example of the emergence of uniqueness that Deleuze refers to. Brown's invention of 'the One'. that emphasis on the downbeat which drives his incessant funk rhythms, would underscore a music of extreme territoriality, and one that 
seemed to directly correspond with the political dynamism of the civil rights era and the broader political environment. To make a further case for the inordinate contribution of diasporic cultures on the production of artistic territorialisation, we might attribute this creativity as part of an ongoing existential non-place/any-space-whatever. This intolerable position being somewhat equivalent to the ongoing 'pain' that Paul Gilroy has argued that the Black Atlantic subject continues to endure (Gilroy 2004: 207), and a pain that has required a sustained campaign of territorial creation ever since.

Which is why my next concern is to draw together the relationship between the anyspace-whatever and Paul Gilroy's Black Atlantic subjectivity; that sense of being present yet never fully belonging, which he refers to as 'double consciousness'. Hence in the course of the rest of this paper I will attempt to bring together what I perceive as the complicit theories of Gilles Deleuze and Marc Augé and their non-place/nonspace/any-space-whatsoevers and how we might bring these concepts of 'non-place' into correspondence with Paul Gilroy's Black Atlantic. For it is in stressing the creative power of non-place that we might otherwise dispense with some of the more simplistic, anthropological attributions of musical identity.

Indeed, no one has been subjected to the spurious attributions of identity that a performer such as James Brown has; where his funk style, for example, is often rather simply presented as a reiteration of 'African' aesthetics. This is the type of description of Brown's music one can find in Craig Werner's A Change is Gonna Come (2002), '...there's no doubt that once the Godfather of Soul took his rhythm stick to 'the one', American music became something different, blacker, and more African than it had ever been before' (Werner 2000: 25). Yet, contrary to this rather nominal, geographical reductionism - my main problem being that it simply negates the cultural complexity of Brown's invention - I would prefer instead, to frame Brown's music within the concept of the 'Black Atlantic' subjectivity, and in doing so, show how this existential habitus, has forced the African-American artist to compensate for this existential non-place via musical composition.

\section{The Black Atlantic}

Paul Gilroy's The Black Atlantic (1993) has deservedly assumed an esteemed place in diasporic theory. The Black Atlantic is a concept used by Gilroy to denote the continual 
process of the transcultural becoming that emerges from this region as a result of African migration - enforced or otherwise. ${ }^{3}$ Rather than engage in discussion built around notions of Eurocentrism or Afrocentrism, Gilroy has instead conceived the Black Atlantic as an attempt to provide a theoretical vehicle for '...an explicitly transnational and intercultural' approach (Gilroy 1993: 15). This approach utilises the concept of the Black Atlantic subject as making sense of an ongoing transcultural exchange between Africa and the West. The appeal of Gilroy's work is that it emphasises the flows constitutive of the fluidity of becoming, rather than attempting to reduce this emergent subjectivity to a nominal identity; a perspective that emphasises an analysis of 'routes' rather than one of 'roots' (ibid. 87). ${ }^{4}$

This focus on 'routes' allows a more sophisticated analysis of the complexity of the pan-continental becoming of the Black Atlantic subject, and thus dispenses with the more simplistic, linear migratory pattern leading from Africa to the West. Instead, Gilroy emphasises the ongoing becoming of both Africa and the new world as a result of the transcultural passages of the Black Atlantic subject. He argues that the best approach to theorising the intellectual and artistic expressions of this ongoing cultural becoming, is through an 'anti-anti-essentialism'(ibid. 101). This anti-anti-essentialist approach might be employed to otherwise overcome the rigid perspectives of essentialism and anti-essentialism, both of which he writes have, '...become an obstacle to critical theorising'(ibid. 101). Whilst the problem of essentialism might seem selfevident, manifest in '... the idea that an untouched, pristine Africanity resides inside these forms, working a powerful magic of alterity in order to trigger repeatedly the perception of absolute identity' (ibid. 101), Gilroy also contends that an anti-essentialist perspective might dismiss completely the necessary relation between race and musical/intellectual production (ibid. 101). Broadly defining these polarities between essentialist and non-essentialist as, '...the relationship between racial identity and racial non-identity, between folk cultural authenticity and pop cultural betrayal' (ibid. 99), ${ }^{5}$

\footnotetext{
${ }^{3}$ As discussed in Paul Gilroy's first chapter, 'The Black Atlantic as a Counterculture of Modernity, 'in The Black Atlantic, (Gilroy 1993: 1-40).

${ }^{4}$ This play on words is the work of cultural studies theorist, Iain Chambers and appears in the text Border Dialogues (New York: Routledge, 1990).

5 To quote the passage in full, 'My point here is that the unashamedly hybrid character of these black Atlantic cultures continually confounds any simplistic (essentialist or anti-essentialist) understanding of the relationship between racial identity and racial non-identity, between folk cultural authenticity and pop cultural betrayal. Here the idea of the racial community as a family has been invoked and appealed to as a means to signify connectedness and experiential continuity that is everywhere denied by the profane
} 
Gilroy looks to an anti-anti-essentialism as a position flexible enough to take into account the concerns of both theoretical positions, to stress the importance of connection without fetishizing 'authenticity' :

The pre-eminence of music within the diverse black communities of the Atlantic diaspora is itself an important element in their essential connectedness. But the histories of borrowing, displacement, transformation, and continual reinscription that the musical culture encloses are a living legacy that should not be reified in the primary symbol of the diaspora and then employed as an alternative to the recurrent appeal of fixity and rootedness (ibid. 102).

Thus Gilroy's appeal to an anti-anti-essentialist approach allows for a discussion of a concept of a 'black music' without it being unduly hampered by the meta-commentary on the ethicality of such a description, yet at the same time being aware enough to maintain a vigilant resistance against the more essentialist appeals to authenticity (ibid. 100).

Gilroy looks to musical examples that are creations of the Black Atlantic and exhibit 'the syncretic complexity of black expressive cultures' (ibid. 101) that emerge from this space. He solicits examples as diverse as The Fisk Jubilee Singers, Jimi Hendrix and The Impressions (ibid. 89-96) as indicative of the Black Atlantic's complex 'circulatory systems'(ibid. 88). Yet I would argue that James Brown's music is also representative of a Black Atlantic syncreticism. Whilst Gilroy does in fact mention James Brown's music, it is only in passing (ibid. 104-105). ${ }^{6}$ Yet I would argue for more emphasis on a performer such as Brown, as he is just as much a product of this conceptual space. Furthermore, and in common with many other Black Atlantic subjects, Brown would similarly have to contend with what African-American scholar, W.E.B. DuBois, has attributed as the 'double consciousness' ${ }^{7}$ of the African-American diasporic subject.

realities of black life amid the debris of de-industrialisation' (Gilroy 1993: 99).

${ }^{6}$ In this section of the Black Atlantic, Gilroy discusses the appearance of a sample of the Average White Band's Pick Up the Pieces, which Gilroy refers to as '.... S Scottish pastiche of James Brown's JBs' (Gilroy 1993: 104-105).

7 The concept of 'double consciousness' derives from W. E. B. Du Bois' The Souls of Black Folk (1903). It appears in the following passage from the opening chapter 'After the Egyptian and Indian, the Greek and Roman, the Teuton and Mongolian, the Negro is a sort of seventh son, born with a veil, and gifted with second-sight in this American world, - a world which yields him no true self-consciousness, but only lets him see himself through the revelation of the other world. It is a peculiar sensation, this doubleconsciousness, this sense of always looking at one's self through the eyes of others, of measuring one's soul by the tape of a world that looks on in amused contempt and pity. One ever feels his two-ness, -an American, a Negro; two souls, two thoughts, two unreconciled strivings; two warring ideals in one dark 


\section{The 'Double Consciousness' of the Black Atlantic Subject}

DuBois' notion of 'double consciousness' might be considered as the inherent existential condition of the Black Atlantic subject. This is a condition symptomatic of the postcolonial subject, who is thrown into an assimilation of multiple worlds, yet lacks any physical territory to which they can wholly belong. As Gilroy says, '[a] preoccupation with the striking doubleness that results from this unique position-- in an expanded West but not completely of it-- is a definitive characteristic of the intellectual history of the black Atlantic (ibid. 58).

This 'double consciousness' inherent in the hybridity of the Black Atlantic will exacerbate a split subjectivity, a condition that many African-Americans, including Brown himself, would have to negotiate. Although I should add that it is not the hybridity itself that is the problem - in fact hybridity is something that is common to us all, the problem is that the minority subject lacks the political power, or the discursive power over its self-determination and identity, which an authoritative relationship to place possible. The Black Atlantic/minor subject, then, must endure the constant becoming of hybridity, yet it is also denied the means to express that difference in an overtly political fashion.

For this reason a minor people including this Black Atlantic subject, might be otherwise regarded, in the Deleuzean sense, as a 'people who are missing' (Deleuze 1989: 217). This is the people that is produced through the work of art and might emerge in the future, as Deleuze has contended in relation to his own examples of artistically driven becoming (ibid. 217). Suffice to say, that it is my belief that musical expression, such as those African-American inventions of jazz, blues, funk and beyond might be seen to contribute to this necessary '...invention of a people' (ibid. 217).

It is in this facilitating of an invention of a people that the arts come into their own. Within intolerable circumstances, the artwork will facilitate an expression of the coexistent temporalities of 'double consciousness' into durable existential territory. The successful artist, then, might be the one who attempts to express the inner temporality of the minority situation through a creative synthesis of time that allows an existential territory to come into being. The art work provides an appropriate catalyst for these new

body, whose dogged strength alone keeps it from being torn asunder' (Du Bois 1903). 
syntheses of time and space, creating a patch of relatively stable territory within a broader state of existential flux. This returns us to the importance of music as a territorialising force, for it expresses time in a new way, often reconceiving relations to broader social movements in the process. The importance of music here is as a force that enables social movements to 'become'. and to assemble new territories through time.

The creation of territory, then, can be seen as a vital need for the minor existence of the 'nomadic space' of the Black Atlantic's existential any-space-whatever condition. This 'nomadic space'. or existential non-place, which initially emerged from an enforced slavery, is further perpetuated through the imposition of enforced economic uncertainty. This is a pattern that has endured for some time: we only have to think, for example, of the pilgrimages by African-Americans from the 1940s who fled the Southern states of the US to move onward to the North to find work. This is also a requirement for many minorities today, where an increasing number of the working poor have to take on menial jobs out of economic necessity, and must suffer the disconnection that such continual economic migration requires. As Mark Anthony Neal informs us in his book, Soul Babies:

[f]or many blacks, whose families migrated to cities like Chicago and Detroit after World War II in pursuit of better job opportunities, the promised land was just that, only a promise. As witnessed by the dire living conditions that the Evans family faced, black migrants were often forced into economic conditions arguably worse than those in the South (Neal 2002: 63).

This economically driven state of enforced transition continues to impose itself upon diasporic communities. Indeed, the lyrics of the black popular music tradition have long referenced such nomadism, enforced or otherwise. Such expression constitutes the whole genre of blues alone, and is also to be found in gospel, work and folk songs. ${ }^{8}$ The music of James Brown often reworked, covered, or merely appropriated this legacy, and his music would continue in this tradition. The development of these styles would be

\footnotetext{
${ }^{8}$ By way of example, one need only to point to the repertoire of an artist such as Robert Johnson, whose songs include paeans to nomadism such as Drifting Blues, Hellhound on my Trail, Walking Blues, and Terraplane Blues. In fact there is a whole other work than could conceivably be addressed in regard to the often-nomadic nature of existence of the African-American, which of course has figured so prominently within the idiom. Although this was not resigned to African-Americans only, but all those who were forcibly dispersed, a sentiment expressed for instance by Woody Guthrie with I Ain't Got No Home.
} 
significant of an attempt to create a musically articulated territory for lives often lived in a state of flux. As such, many of Brown's songs capture a sense of a (often enforced) nomadism that was common to the experience of many African-Americans. This is an experience articulated through tracks such as 1961's 'Night Train', in which Brown sings out the major stops of the 'Chitlin Circuit'. or 1967's 'There Was a Time' in which the audience is invited to chant the praises of his hometown, '...Augusta GA' from all points across North America (Brown 1967).

Indeed James Brown's fondness for mythologising the South might be perceived as the epitome of a nostalgia for a virtual time and space, a concept that I have referred to in previous essays as an 'apprehension of a minor temporality'. The South provides a source of common cultural association and is about as close to home, existential or otherwise, for many African-Americans as they can plausibly lay claim to. We only have to think about the use of the term 'down home'. as many African-Americans have referred to the South, as an example of this attempt to create a sense of home for a people made nomadic due to their economic position.

In short, we might say that the music of an artist such as James Brown was driven by a lack of belonging rather than some unspecified African musical lineage. By extension, I would then argue that not only these, but that all styles of musical expression are not so much about identification with place, but rather are concerned with the artistically driven results that emerge from the paradox of inhabiting the non-place.

This Black Atlantic condition, which could be seen as a protracted any-space-whatever situation, has enticed its subjects to artistically create spaces in lieu of the physical belonging to place that has been otherwise denied them. Indeed, it is under similar conditions of duress that African-American musical creativity continues to flourish, as art becomes the catalyst in the mediation of conceptual space, in lieu of a connection with actual, material space. Given the nature of the disparate circumstances of any diasporic community, they cannot fully possess a shared collective memory of the past together, but perhaps only a future. At this point the artist must intervene to bring together these disparate populations, the concept referred to in Deleuze and Guattari's, $A$ Thousand Plateaus (1987) as the 'problem of the people' : 
...the artist opens up to the Cosmos in order to harness forces in a work ${ }^{6}$ (without which the opening onto the Cosmos would only be a reverie incapable of enlarging the limits of the earth); this work requires very simple, pure, almost childish means, but also the forces of a people, which is what is still lacking' 'We still lack the ultimate force ...We seek a people (Deleuze \& Guattari 1988: 337-338).

Deleuze and Guattari contend that the art work seeks a people, because it creates its audience: '[w]hen Klee says that the people is missing, what is at stake is the mode of individuation of a people, which should be that of a becoming, a multiplicity that is irreducible to the terms of the one and the Many'(Bogue 2003: 42). We should then conceive of the role of the artist, and in this case, the musical artist as attempting to overcome the chaos of the non-place/any-space-whatever by creating a territorial consistency via the musical composition. For art's very power is derived from this rediscovery of the infinite as it opens up the possibility of eternal difference. As Deleuze and Guattari contend, the work of art mediates the constant movement from 'chaos to composition' (Deleuze \& Guattari 1994: 203). In this respect, we might be able to reflect on why diasporic subjects, such as the African-American and/or Jewish communities of the West, have traditionally made inordinate contributions to the arts. It may well be that as these subjects, lacking a true relatioship to place, are instead subsumed in the chaos of the infinite - the chaos that permeates the non-place/anyspace-whatever of the diasporic experience - and they have turned that chaos into artistic composition in order to make territory where there was none.

\section{Bibliography}

Augé, M. (1995) Non-Places: Introduction to an Anthropology of Supermodernity, trans. J. Howe, New York: Verso.

Bell, J. A. (1997) 'Thinking with Cinema: Deleuze and Film Theory', Film-Philosophy, 1(8), available online at http://www.film-philosophy.com/vol1-1997/n8bell, 3 August 2004.

Deleuze, G. (1986) Cinema 1: The Movement-Image, trans. H. Tomlinson and B. Habberjam, Minneapolis: University of Minnesota.

Deleuze, G. (1989) Cinema 2: The Time Image, trans. H. Tomlinson and R. Galeta, London: Athlone Press.

Deleuze, G., and Guattari, F. (1988) A Thousand Plateaus: Capitalism and Schizophrenia, trans. B. Massumi, London: Athlone Press.

Gilroy, P. (1993) The Black Atlantic: Modernity and Double Consciousness, Cambridge, Mass: Harvard University Press. 
Gilroy, P. (2004) 'It's a Family Affair', in M. Forman and M. A. Neal (eds), That's the Joint! The Hip-Hop Studies Reader, New York: Taylor and Francis: 87-103.

Keyes, C. L. (2002) Rap Music and Street Consciousness, Urbana, Ill.: University of Illinois Press.

Massumi, B. (1992) A User's Guide to Capitalism and Schizophrenia: Deviations from Deleuze and Guattari, Cambridge, Mass.: MIT Press.

Neal, M. A. (2002) Soul Babies: Black Popular Culture and the Post-Soul Aesthetic, New York; London: Routledge.

Stivale, C. J. (2005) 'Duelling Augé's - Pascal and Marc', August 11, 2005 available online at from http://www.langlab.wayne.edu/CStivale/D-G/DuellingAuge.html, 15 March 2006.

Werner, C. (2000),A Change Is Gonna Come: Music, Race and the Soul of America, Edinburgh: Payback.

\section{Discography}

Brown, J. (1967), 'There Was a Time', King.

Brown, J. (1971a), 'Escape-Ism Pt.1 and Pt.2', Polydor.

Brown, J. (1971b), Revolution of the Mind - Live At the Apollo Vol. 3, Polydor.

Brown, J. (1971/1991), Hot Pants (re-issue). New York: Universal. 